\title{
AZ EGYETEM MELLETTI MUNKAVÉGZÉS SEGÍTŐ ÉS GÁTLÓ TÉNYEZŐI DIÁKSZEMMEL \\ - KÉRDŐÍVES FELMÉRÉS A BCE, BGE ÉS BME MESTER- SZAKOS HALLGATÓI KÖRÉBEN
}

Az utóbbi évek felsőoktatási tapasztalata, hogy egyre magasabb a munkát vállaló nappalis mesterszakosok aránya a gazdálkodástudományi képzésekben. Ez a helyzet napjaink egyik izgalmas munkaerō-piaci tendenciájaként fogható föl. A mestertanulmányok melletti munkavégzés nemzetközi és hazai vizsgálatai során ritkán esik arról szó, hogy milyen kihívásokkal, nehézségekkel és esetleges előnyökkel jár ennek az élethelyzetnek a megélése, illetve min múlik az, hogy az elónyös vagy hátrányos hatások kerekednek felül, illetve milyen szereppel és felelósséggel bírnak a különböző szereplők (hallgatók - munkáltatók - egyetem). Az érintetti kör kölcsönhatásainak komplexitására való tekintettel átfogó kutatást végeztek a szerzők, melynek során a hallgatók online kérdoóven és fókuszcsoportos megkérdezéseken, az egyetemi vezetók (szakfelelősök, kari vezető́k, oktatási szakértők) és a munkáltatók képviselői pedig interjúkon és egy háromoldalú (egyetemi oktatók, munkáltatók és hallgatók képviselői) párbeszédet elósegítő workshopon osztották meg velük tapasztalataikat.

A cikkben az elsố lépést teszik meg eredményeik bemutatásában, ahol alapvetôen a szerepelméletre épülő, zárt és nyílt kérdéseket egyaránt alkalmazó online kérdőíves felmérésre építettek. A késóbbiekben kiegészítik ezen eredményeket a hallgatói fókuszcsoportos adatok értelmezésével, valamint az egyetemi és munkáltatói oldal észlelésével és csak ezt követően szeretnék a klasszikus értelemben vett következtetéseket és ajánlásokat megfogalmazni. ${ }^{1}$

Kulcsszavak: egyetem melletti munkavégzés, mesterképzés, szerepelmélet, egyetem

Az egyetemi oktatóként is észlelt jelenségkör empirikus vizsgálatára s a hallgatói munkavállalással összefüggésben megtapasztalt kölcsönhatások szisztematikus tanulmányozására a „Közösen a jövő munkahelyeiért” Alapítvány 2015 őszén kiírt pályázata biztosított lehetôséget számunkra. Cikkünkben átfogó kutatásunk azon eredményeit mutatjuk be, melyek a hallgatói munkavállalással kapcsolatos egyes szerepek közti kölcsönhatásokra, a munkavállalás motivációjára, valamint a munka-tanulás-magánélet viszonyát formáló tényezőkre vonatkoztak.

Kutatásunk aktualitását a gazdálkodási szakon tanuló mesterszakos hallgatók magas munkavállalási aránya jelenti, amely az elmúlt években - amint azt a következőkben részletesen is ismertetjük - nem csökken, így méltán feltételezhetjük, hogy egy tartós trenddel van dolgunk, amelyre rendszerszintú válaszok szükségesek. Ez utóbbiak megtalálásához szükséges a hallgatói oldal mélyebb megértése, az általuk megtapasztalt problémák feltárása.

A bevezetés után a probléma kiterjedtségét jellemzô hazai statisztikai adatok áttekintése, majd a kutatás legfőbb elméleti keretrendszeréül szolgáló szerepelmélet idevonatkozó megállapításainak rövid bemutatása következik. Jelen vizsgálatunk módszertani keretének ismertetése előtt összefoglaljuk azon feltáró kutatás legfőbb eredményeit is, melyet empirikus munkánk közvetlen előzményének tekintettünk. Leíró statisztikai eredményeink ismertetését követóen bemutatjuk, hogy sokváltozós elemzésünk nyomán milyen faktorok mentén, s milyen klaszterekkel jellemezhetó a munkavállalásban érintett hallgatói minta, majd kitérünk 
a kérdőíves vizsgálat nyílt kérdéseire kapott válaszok elemzésére. Tanulmányunk záró fejezetében azok a hallgatói „szerepértelmezések” és „helyzetészlelési mintázatok" kerültek fókuszba, melyek mentén eredményeink a jövőbeni problémakezelés különféle potenciális lehetőségeit megelőlegezik.

\section{A mesterszak melletti munkavállalás kiterjedtsége}

Kutatásunk szempontjából alapvető kiinduló kérdést jelent, hogy vajon mennyire kiterjedt a hazai felsőoktatásban tanuló fiatalok körében a munkavállalás a rendelkezésre álló adatok szerint? Ehhez alapvetően a témában született korábbi tanulmányokat, a DPR (Diplomás Pályakövető Rendszer) Hallgatók 2011 és a Hallgatók 2012 kutatásait és a KSH 2006. IV. negyedévi és a 2010. IV. negyedévi munkaerő-felmérés kiegészítő felvétele alapján készített tanulmányokat (KSH, 2007; $\mathrm{KSH}, 2011)$ vettük kiindulópontul.

A fiatalok munkaerő-piaci helyzetéról szóló KSH-kiadványok szerint a 15-29 évesek körében 2006-ban a nappali tagozaton tanulók 11,1\%-a, 90 ezer fó nyilatkozott úgy, hogy tanulmányai mellett az elmúlt egy évben dolgozott valamikor, míg 2010-ben már 20,9\%-uk, 189 ezer fó. Ezen belül 2006-ban 10,8\% volt azok aránya, akik az év egészében rendszeresen dolgoztak, amiból az egyharmaduk kötelező szakmai gyakorlat miatt dolgozott, míg közel felük önszántából, elsősorban jövedelemszerzés céljából. 2010-ben már 35,4\% volt azok aránya, akik nappali tagozatos tanulmányaik mellett az év egészében rendszeresen dolgoztak, 53,9\%-uk tette mindezt kötelező szakmai gyakorlat keretében (KSH, 2007, p. 20-21.; KSH, 2011, p. 21.).

A 2011-es jelentésben szerepel még egy nagyon hasznos adat, ami szerint a munkát vállaló nappali tagozatos diákok naponta átlagosan 6,3-6,8 órát dolgoznak, ami öt munkanappal számolva heti szinten 31,5-34 órát jelent. Ez utóbbi kiadvány a növekedés ellenére azt állapítja meg, hogy a nappali tagozaton történó munkavégzés nem igazán gyakori hazánkban, illetve az iskola által szervezett, iskolai programokhoz kapcsolódó munkavégzés sem igazán jellemző a magyar diákokra (KSH, 2011).

A fenti megállapításhoz képest egészen mást mutatnak a DPR Hallgatók 2011 Veroszta (2012) és Hallgatók 2012 Veroszta (2013) eredményei, ami alapján a tanulmányaik mellett munkát is vállaló hallgatók aránya 2011-ben 42,8\%, míg 2012-ben már 44,8\%, ez az adat azonban tartalmazza az esti, levelező és távoktatási munkarendben tanulók 90\%-ot megközelítő munkavállalási arányát.

A nappali tagozatosok esetében 2011-ben 26,7\% volt, míg 2012-ben kicsit nagyobb, 28,1\% volt a párhuzamosan munkát végzők részaránya. Nagyon fontos adat, hogy a képzési rendszer második lépcsőjében az MSc-képzésben a leggyakoribb a tanulmányok melletti munkavégzés, mely 2011-ben 59,9\%, majd 2012-ben közel ugyanannyi, 59,3\%, azonban ez nemcsak a nappali munkarendben tanulókat jelenti. Ugyanígy nincs megkülönböztetve ez a képzési területek szerinti adatoknál, ami alapján a gazdaságtudományi területen ennél valamivel alacsonyabb arányú a munkavégzés: 2011-ben 52,8\%, míg 2012-ben 53,4\%. A téma szempontjából érdemes megjegyezni azt is, hogy a tanulmányok mellett végzett munka és a tanulmányok szakterületének illeszkedése a mesterképzések hallgatóinak körében a legerősebb, mindkét évben $80 \%$ feletti.

Az idézett tanulmányokhoz képest kutatásunkban kifejezetten a gazdálkodástudományi mesterszakokra és ezen belül is a legmagasabb felvételi pontszámokkal jellemezhetô, tradicionálisan a hazai gazdasági elit képzési helyeinek számító intézmények (Budapesti Corvinus Egyetem, Budapesti Múszaki Egyetem és Budapesti Gazdasági Egyetem) mesterhallgatóira koncentráltunk. Ezeknek az „elit szakoknak” a gyakorlata, a szakok tematikája, tananyagai, oktatási módszertana stb. nagyon sok szempontból meghatározó mintát jelentenek más egyetemek hasonló képzései számára, amibe valószínúleg olyan kérdések is beletartoznak, hogy hogyan viszonyuljanak a hallgatók munkavállalásához, illetve más, aktuálisan napirenden lévő kérdésekhez, például a duális képzéshez. Természetesen nem egy az egyben történő másolásról van szó, hanem egyfajta adaptív viszonyulásról, de a kutatási terep meghatározásakor azt feltételeztük, hogy mint vonatkoztatási keret, mindenképpen megjelenik a vizsgált intézmények gyakorlata.

\section{Az egyetem melletti munkavégzés vizsgálata a szerepek tükrében}

A tanulmányok melletti munkavégzés vizsgálata során ritkán esik arról szó, hogy milyen kihívásokkal, vagy éppen előnyökkel jár ennek az élethelyzetnek a megélése. Ugyanis aki rendszeresen és tartósan dolgozik tanulmányai mellett, annak a hallgatói szerep mellett a munkavállalói szerepet is be kell töltenie. A különböző szerepek betöltésének kérdése a kisgyermekes anyák, vagy általában a családos munkavállalók esetében merül fel, mivel ezeket a szerepeket tartósan kell megfelelóen betölteni és összehangolni. Nemcsak az egyén jólléte (well-being) miatt, hanem a munkahelyi teljesítőképesség fenntartásáért, illetve a család és a tágabb közösség érdekében is. Ez a felismerés vezetett az emberierőforrás-menedzsmenten - mint vállalati funkción és szakterületen - belül a munka-magánélet egyensúly kérdésének felismeréséhez, és ez motiválja a megfelelő munkahelyi gyakorlatok, körülmények kialakításának igényét. A munka-tanulás-magánélet viszonyrendsze- 
rének szerepelméletekre alapozó kutatása ennek analógiájára alakult ki később a külföldi szakirodalomban. A modell alkalmazása lehetôséget biztosít a munka-tanulás-magánélet viszonyának feltárására, valamint a köztük kialakuló összefüggéseket moderáló lényeges változók vizsgálatára. Jelen cikkben a karriertudatosság befolyásoló hatását vizsgáltuk a szerephalmozásra.

A szerep fogalmának interperszonális megközelítése szerint az egyének szerepviselkedésen keresztül érintkeznek egymással, melyben viselkedésüket az elvárásokról alkotott elófeltevéseik alakítják, melyek az interakció dinamikájában folyamatosan változnak. Amikor nem a felsőoktatási intézmény által szervezett vállalati gyakorlatról van szó, akkor megnő annak a valószínúsége, hogy a hallgatói munkavállalás célja nem elsősorban a tanulás, hanem az érdemi munkavégzés. Így a tanulói és a munkavállalói szerepek együttesen vannak jelen a hallgató életében, mely a lehetséges viselkedési minták, illetve a jogok és kötelességek növekedésével jár.

A szerepek egymásra hatásánál két, egymástól eltérő megközelítés különíthetô el a szakirodalomban: az ún. szúkösségi (scarcity) és a bővítési (expansion) megközelítések, melyek időben egymást követően alakultak ki. Kezdetben a szerepelméleti kutatások alapvetôen azt feltételezték, hogy a több szerepet betöltő egyének erőforrásai szúkösek és végesek (Goode, 1960; Moore, 1960; Slater, 1963; Snoek, 1966). Később ennek kritikájaként születtek olyan publikációk, melyek felvetették a rendelkezésre álló energia bővítésének lehetőségét (Sieber, 1974; Marks, 1977). A szúkösségi megközelítés tipikus felfogása szerint ,tekintettel az idő és az energia szúkösségére, a szerepkonfliktus valószínúsége a több szerepet betöltőknél magasabb" (Moore, 1960, p. 108.), tehát a több szerepet betöltőknek meg kell osztaniuk erőforrásaikat közöttük. Mivel a szerepek alapvetően versengenek a szerep iránti nagyobb elkötelezettségért, ennek egyenes következménye a szereptúlterheltség és a szerepstressz, továbbá a kompromisszumok és az alkudozás ebben a zéróösszegú játszmában (Kiss, 2013).

A szúkösséggel szembeni kritikák jórészt azon alapultak, hogy az addigi elméletek nagy része a több szerep betöltésével járó természetes következményként tüntette fel a konfliktust, viszont ezt nem bizonyították semmiféle empirikus kutatással. Amennyiben történtek erre kísérletek, azok ugyanezen az előfeltevésen alapulva például az eszközökben kizárólag csak negatív megfogalmazású kérdésekkel vizsgálták a jelenséget (Sieber, 1974). Ezzel szemben viszont például Sieber azt feltételezte, hogy különféle pozitív következményei is lehetnek a szerephalmozódásnak, amelyek felülmúlják a stressz negatív hatását. Négy kategóriába sorolta ezeket: (1) szerepprivilégiumok, azaz a szerepek nemcsak kötelezettségekkel járnak, hanem jogokkal is - így több szerep, több jogot is jelent, (2) általános státusbiztonságot, azaz annak a lehetóségét, hogy az egyik szerep kompenzálhatja a másik kudarcait, ami később pozitívan hat vissza rá, (3) eróforrásokat a státus fejlesztéséhez és a szerepben nyújtott teljesítményhez, például a kapcsolati tôke növelésén keresztül, (4) a személyiség gazdagodása és az önbecsülés, rugalmasság növekedése, unalom elkerülése (Sieber, 1974, p. 569.).

Az expanziós elmélet (Marks, 1977) jóval többet feltételezett annál, mint hogy a pozitívumok ellensúlyozzák és felülmúlják a negatívumokat, ugyanis alapvetóen nem zéróösszegú játszmának tekinti a szerepek betöltését. Abból indult ki, hogy a fizikai és a szellemi energia felhasználása és előállítása egybekapcsolódik, és így megújuló módon és bőségesen az egyén rendelkezésére áll, amennyiben az egyformán elkötelezett a szerepei iránt. Tehát nem az a természetes, hogy a nap folyamán csak kifelé áramlik az energia és kimerülnek az eróforrásai. Ezek a negatív érzések csak akkor bukkannak fel, amikor az egyén valamelyik szerepét kevésbé tartja fontosnak (és így kevésbé elkötelezett iránta), tehát szívesebben lenne egy másik szerepében akkor is, amikor éppen nem teheti ezt meg (Marks, 1977).

A szúkösségi megközelítés egyik nagy hatású elmélete szerint (Greenhaus - Beutell, 1985) a munka-család konfliktusnak három formája különíthető el: az időalapú, a stresszalapú és a magatartás-alapú. Az időalapú konfliktus azt jelenti, hogy az egyik terület elvárásainak való megfeleléshez szükséges idő felemészti a másik terület elvárásainak kielégítéséhez szükséges időt. A stresszalapú konfliktus esetében az egyik területen keletkező stressz negatívan hat a másik területre, mintegy átsugárzik arra is. Magatartás-alapú konfliktusról akkor beszélünk, amikor az egyén egyik területen bevált viselkedései nem megfelelóek a másikon, viszont nem képes ezen változtatni (Greenhaus - Beutell, 1985).

Az egyik szerző, Greenhaus, később szükségét látta annak, hogy a már alaposan kutatott munka-család konfliktus után elkezdje vizsgálni a másik oldalát is a kérdésnek, azaz hogy lehetséges-e a bővítés, a két terület pozitív kölcsönhatása. Ezt munka-család gazdagításnak nevezték el (Greenhaus - Powell, 2006) és azt feltételezték, hogy az egyik életterületen megszerzett erőforrások közvetlenül vagy közvetetten - az érzelmeken, a hatékonyság javulásán, az önbizalom növekedésén keresztül - javíthatják a másik területen tapasztalt életminőséget.

Egyes szerzők (McNall - Michel, 2011; Wyland - Lester - Mone - Winkel, 2013) alapján ezek a tényezók a munka és az iskola viszonylatában is megjelennek, nemcsak a munka és a család területén, mivel az elméletek inkább általánosságban a szerepekre vonatkoznak, mint csupán egy-egy speciális területre. Tulajdonképpen a foglalkoztathatóság (employability) 
koncepciója is ebbe a vonulatba sorolható be (Forrier - Sels, 2003; Knight - Yorke, 2006). Hazai szerzők közül Kiss Zsuzsanna (2014) doktori disszertációjában szereplő meghatározás egy tág értelmezési keretet ad: „Foglalkoztathatóság alatt a munkaeró-piaci sikeresség szinonimájaként annak valószínúségét értem, hogy az egyén az elképzeléseinek megfelelő munkát talál, amit számos tényezó befolyásol. Ezek a tényezők: a foglalkoztatáspolitikai intézkedések, a képzés során elsajátított ismeretek, az iskolából a munka világába való átmenet körülményei, a munkakör által megkövetelt tudások típusa, az idő, a képességek, a készségek, a munkaerő-piaci lehetőségek" (Kiss, 2014, p. 5.).

Mivel a témával kapcsolatos kutatásokat sokszor felsőoktatásban dolgozó kutatók vagy felsőoktatási szakértők végzik, nem meglepő, hogy kiemelt figyelmet kap a hallgatók munkavégzésének a tanulmányi eredményeikre, iskolai teljesítményükre gyakorolt negatív hatása, a tanulásra fordított idő csökkenése, a tanórák látogatásának elmulasztása, az iskolai tevékenységek kihagyása, a határidők be nem tartása, a megnövekedett stressz és fáradtság (Carney - McNeish - McColl, 2005; Lindsay - Paton-Saltzberg, 1994; Ford - Bosworth - Wilson, 1995; Sorensen - Winn, 1993; Silver - Silver, 1997). Ugyanígy a tanórán kívüli tevékenységekre (extracurricular activities) - köztük a sportolásra és az önkéntes tevékenységekre - fordított idő csökkenéséről számoltak be a kutatásban részt vevő hallgatók (Lindsay - Paton-Saltzberg, 1994; Meyer, 2001; Taylor - Smith, 1998).

Még ha kisebbségben is vannak, de megjelennek a kutatási eredmények között olyanok is, amelyek a munkavégzés pozitív hatásairól számolnak be - különösen azoknál, akik a tanulmányaik területéhez kapcsolódó munkát végeznek (Hodgson - Spours, 2001; Lucas, 1997). A pozitív hatások között a tudás és a készségek elsajátítása (Callender - Kemp, 2000; McKechnie - Hobbs - Lindsay, 1997), a felsôoktatás és a munkaerôpiac közötti átmenet megkönnyítése (Hakim, 1996), az önbizalom növekedése, valamint az időgazdálkodás és a kommunikációs készségek fejlődése jelentek meg, melyek mind hozzájárulhatnak a foglalkoztathatóság növekedéséhez.

Tekintettel arra, hogy a karrierúton betöltött szakmai szerepek értelmezésében és megformálásban, a karrieralkalmazkodást vizsgáló empirikus kutatások széles köre (Brown - Lent, 2013; Creed et al., 2004; Duffy, 2010; Jadidian - Duffy, 2012; Judge - Bono, 2001; Luzzo, 2006; Rottinghaus et al., 2012) igazolta a moderátortényezők tudatosulásának jelentóségét, vizsgálatunk kiterjedt a hallgatók karriertudatossági szintjének mérésére is. A karriertudatosság fogalmát jelen vizsgálatunk során úgy definiáltuk, mint a hallgató azon képességét, mellyel megítéli, mennyire van tisztában saját hosszú távú foglalkoztathatósági és növekedési feltételeivel. Azok a hallgatók, akik „karriertudatosabbak", jobban tudják mit kell tenniük ahhoz, hogy az általuk választott szakterületen eredményesen fejlődhessenek, s a munkaeró-piacon szándékaiknak megfelelően elhelyezkedjenek, s teljesítóképesek legyenek.

A fentiekben részletezett eredmények egybevágnak azokkal a kutatásokkal is, amelyek az egyetem mellett végzett munka szakmai illeszkedésének jelentőségére hívják fel a figyelmet. Ez számunkra kiemelten fontos, mert feltételezésünk szerint a vizsgált mesterszakokon a legtöbben nem a megélhetésükért és a tandíjuk kifizetéséért dolgoznak (többségében államilag finanszírozott képzések ről lévén szó). Ez pedig lehetővé teszi számukra, hogy olyan, szakterületükhöz kötődő, érdeklődésüknek megfelelő munkát is elvállaljanak, ami ugyan nem jövedelmezó, de mégis pozitívan hat akár már a pillanatnyi helyzetükre, de különösen a munkaeró-piacra való átmenet gördülékennyé tételére és későbbi életútjukra is. Következésképpen a hallgatók karriertudatosságának jelentős moderáló hatást tulajdonítottunk, és beépítettük a szerephalmozás összefüggéseit vizsgáló kérdőívünkbe.

\section{A szerepelméleti megközelítés egy hazai elózménye}

Hazai elózményként fontos megemlíteni Németh Márton (2015) feltáró jellegú kutatását, amely szintén a fenti vonulatba illeszkedik, megpróbálva beazonosítani a legfontosabb pozitív és negatív hatásokat és szerepkonfliktusokat. A 99 nappali tagozatos BCE gazdálkodástudományi kari mesterszakos hallgató kérdőíves megkérdezésére és 9 fővel készített interjús kutatása jelen kutatás számára is fontos kiindulópontként szolgált.

A kutatás alapján a válaszadók háromnegyede (74,75\%-a) dolgozott a kérdőív kitöltésének időpontjában, míg további tizenöt százaléknyian dolgoztak már a mesterképzés alatt, de akkor éppen nem voltak munkavállalói szerepben. Az első két félévben volt a legmagasabb azoknak a száma, akik még csak tervezték a munkavállalást, az utolsó két félévükben járók között pedig megfigyelhetôk olyanok, akik már nem dolgoznak, de a mesterképzés során szereztek munkatapasztalatot. Rajtuk kívül van legalább 60\%-nyi olyan hallgató is, akik végig dolgoztak a 4 félév során, a mesterképzéssel párhuzamosan.

A munkatapasztalattal már rendelkező 88 hallgató átlagosan 19,84 hónapot, és átlagosan 3,09 különböző munkahelyen dolgozott. Csak 13,48\%-uk volt még mindig annál a vállalatnál, ahol előtte kötelező szakmai gyakorlatát töltötte. A hallgatók 89,89\%-a olyan munkát végzett, ami kapcsolódik a tanulmányaihoz. A hallgatók 77,53\%-a maradt volna szívesen az ak- 
kori gyakorlati helyén a diplomázását követően is, de aki egy munkahelyen szerzett még csak tapasztalatot, az nagyobb valószínúséggel próbálna ki másikat is. A munkavállalás okaira vonatkozó nyílt kérdésekre adott válaszokból kiderült, hogy legtöbbször a tapasztalatszerzést, majd második leggyakoribb okként a pénzt említették, amihez képest más okok gyakorisága 70$80 \%$-kal alacsonyabb volt.

A fenti kutatás ugyan nem tekinthetó az elemszáma alapján reprezentatívnak, de vizsgálta a munka-iskola viszonyrendszer szerepelméleti vonatkozásait is. Három faktor mentén értelmezte a válaszok struktúráját, és ez alapján klaszterelemzéssel három, egymástól elkülönülő csoportba sorolta az egyetem mellett munkát vállaló hallgatókat. Az első klaszter (iskolai szerephez kötődők) tagjai átlag alatti konfliktust észleltek a szerepek között, és rájuk jellemző leginkább az a vélekedés, hogy az iskolai szerep gazdagítja a munkahelyit, de egyúttal ők gondolják legkevésbé úgy, hogy a munkahelyi szerep gazdagítaná az iskolait. A második klaszter (munkahelyi szerephez kötődők) tagjainál is átlag alatti a konfliktus mértéke, viszont szerintük a munkahelyi szerep hat pozitívan az iskolaira. A harmadik klaszter (a két szerep közt őrlődők) tagjaira jellemző mindhárom közül leginkább az, hogy nagyfokú konfliktust tapasztalnak meg a hallgatói és a munkahelyi szerepük között, míg szerintük ezek csak átlagos mértékben gazdagítják a másikat.

A kvantitatív és kvalitatív kutatás alapján a három klaszter között létezik átmenet. A mesterképzés elején a legtöbben még az „iskolai szerephez kötődőkhöz” tartoznak, majd a képzés elsô szakaszának sikeres teljesítése után megnó a valószínúsége annak, hogy az egyetemmel párhuzamosan dolgozni kezdenek. A hallgatók egy része a munkatapasztalatának növekedését úgy éli meg, hogy a munkavállalói szerepbe egyre jobban beleszokik, és megerősödik az ehhez való viszonya. Akinek ezzel párhuzamosan csökken az iskolához való kötődése, az átkerül a második, ,,munkahelyi szerephez kötődők" klaszterbe. Akiknél nem ennyire folytonos és egyértelmú a kötődés átalakulása, azok tartoznak a harmadik, „két szerep között őrlódők" klaszterhez egyetemi tanulmányaik befejezéséig, ugyanis akik mindkét szerepükhöz kötődnek, azoknál a legnagyobb az időalapú konfliktus valószínúsége, akik pedig egyikhez sem kötődnek igazán, azoknál a legkisebb az esélye annak, hogy az egyik szerepükben aktuálisan megélt sikerük kompenzálni tudja a másik szerepük kudarcát.

\section{Módszertani keretünk}

Az online kérdőív segítségével a következő kutatási kérdések megválaszolására törekedtünk:
- Hogyan észlelik a hallgatók a munka-tanulás-magánélet viszonyát?

- Hogyan hat a fentiek észlelésére a munkavállalás motivációja, a karriertudatosság?

- Melyek a munka-tanulás-magánélet egyensúlyát támogató és gátló tényezők?

A kérdéseket megválaszolandó a kérdőívet a következő témakörök mentén állítottuk össze:

- a munkavállalással kapcsolatos motivációk,

- a foglalkoztatás jellemző adatai,

- munka-tanulás és tanulás-munka gazdagítás/szegényítés,

- szerepkonfliktusok,

- a munka-tanulás-magánélet egyensúly kritikus tényezői,

- karriertudatosság,

- háttérváltozók.

A kérdőív több elágazást is tartalmazott, a munka-tanulás vonatkozásában egyaránt kíváncsiak voltunk a jelenlegi és/vagy ${ }^{2}$ a múltbeli tapasztalatokra, akiknek egyik sem volt, azoknál azt a kérdést igyekeztünk körüljárni, hogy miért döntöttek úgy, hogy nem vállalnak munkát a mesterszak alatt. Aki korábban dolgozott, jelenleg azonban nem, azoknál pedig arra voltunk elsősorban kíváncsiak, hogy vajon miért függesztették fel a munkavállalást. A kérdésekre adott válaszok átlag és szórás értékeit az 1., 2. és 3. táblázatok tartalmazzák.

A kérdőív nyitott kérdéseit a kvantitatív elemzés során azonosított hallgatói csoportok mentén elemeztük. Célunk a munka-tanulás-magánélet viszonyának részletesebb feltárása volt a következő lépések mentén: (1) kerestük azon kritikus tényezőket, amelyek mindegyik csoportban támogató vagy gátló elemként jelentek meg, valamint (2) azonosítottuk az eltéró intenzitásúnak észlelt konfliktusok mögött meghúzódó magyarázó elemeket, és (3) a gazdagító vagy szegényító hatás lehetséges mögöttes okainak feltárására is tettünk kísérletet. Tematikus adatelemzést alkalmaztunk: két kutató egymástól függetlenül kódolta az egyes csoportok válaszait, majd közösen alakították ki a cikkben leírt értelmezést.

A kérdőíves adatfelvételre 2016. május-júniusában került sor. $\mathrm{Az}$ online kérdőívet mindenhol a mesterszakok szakfelelősei küldték ki a hallgatóknak (mind a négy évfolyamnak). A kérdőívet összesen 435 fó töltötte ki az alábbi intézmények szerinti megoszlásban: BCE: 283 fó; BME:139 fó és BGE: 16 fó. A válaszadók mesterszakok szerinti megoszlását a 4. táblázat foglalja össze. 


\section{Az elsó és második munkahelyesek munka-tanulás egyensúlyát jellemző kérdések átlag- és szórásértékei}

Kérdés

2. MH (145 fö) 1 1. MH (164 fö)

\begin{tabular}{|c|c|c|c|c|}
\hline & Átl. & Szórás & Átl. & Szórás \\
\hline Mióta dolgozol jelenlegi munkahelyeden? & 5,07 & 2,39 & 5,49 & 2,16 \\
\hline Szakmai tapasztalat szerzésének fontossága jövőbeli szakterületen. & 4,66 & 0,63 & 4,66 & 0,64 \\
\hline „Tanulmányaim és megélhetésem finanszírozásához pénzre volt szükségem” - állítás fontossága. & 4,10 & 1,15 & 3,94 & 1,08 \\
\hline Tapasztalat szerzésének fontossága üzleti szervezetek múködésével kapcsolatban. & 4,19 & 0,90 & 4,25 & 0,87 \\
\hline „Későbbi elhelyezkedésemhez előnyös, ha van munkatapasztalatom” - állítás fontossága. & 4,71 & 0,67 & 4,71 & 0,64 \\
\hline Saját autonómiám megteremtésének fontossága. & 4,19 & 0,90 & 4,12 & 0,81 \\
\hline Heti átlagban mennyi a ténylegesen munkával töltött időd? & 29,4 & 10,2 & 25,8 & 9,1 \\
\hline Mennyit keresel egy hónapban átlagosan? (e Ft-ban, nettó) & 115,6 & 72,8 & 100,4 & 69,9 \\
\hline Kapcsolódik az általad jelenleg végzett munka az eddigi, vagy mostani tanulmányaid területéhez? & 1,08 & 0,28 & 1,16 & 0,37 \\
\hline $\begin{array}{l}\text { A munkahelyi tevékenységekben való részvételem segít abban, hogy több tudásra és jobb képessé- } \\
\text { gekre tegyek szert. }\end{array}$ & 4,50 & 0,83 & 4,45 & 0,79 \\
\hline $\begin{array}{l}\text { A munkahelyi tevékenységekben való részvételem hozzásegít, hogy az egyetemi tananyagot mélyeb- } \\
\text { ben elsajátítsam. }\end{array}$ & 3,07 & 1,20 & 2,79 & 1,17 \\
\hline $\begin{array}{l}\text { A munkahelyi tevékenységekben való részvételem arra ösztönöz, hogy fókuszáltan használjam fel a } \\
\text { tanulmányaimra fordított időmet. }\end{array}$ & 3,65 & 1,23 & 3,77 & 0,98 \\
\hline $\begin{array}{l}\text { A munkahelyi tevékenységekben való részvételem időben gyakran ütközik a tanulmányaimmal kap- } \\
\text { csolatos kötelezettségeimmel. }\end{array}$ & 3,76 & 1,25 & 3,57 & 1,24 \\
\hline $\begin{array}{l}\text { A munkahelyi tevékenységekben való részvételem miatt gyakran az iskolai tevékenységek közben is } \\
\text { a munkahelyi dolgokon jár az agyam. }\end{array}$ & 3,21 & 1,39 & 2,70 & 1,24 \\
\hline $\begin{array}{l}\text { A munkahelyi tevékenységekben való részvételem során használt gyakorlatias megközelítés hasznos- } \\
\text { nak tűnik a tanulmányaim során is. }\end{array}$ & 3,94 & 1,03 & 3,71 & 1,11 \\
\hline $\begin{array}{l}\text { A munkahelyi tevékenységekben való részvételem során fejlesztett kommunikációs és együttmúködé- } \\
\text { si készségek a tanulmányaim során is jól hasznosulnak. }\end{array}$ & 4,08 & 1,00 & 3,97 & 1,05 \\
\hline A mesterképzésben való részvételem segít abban, hogy több tudásra és jobb képességekre tegyek szert. & 3,70 & 1,24 & 4,01 & 1,01 \\
\hline A mesterképzésben való részvételem segít abban, hogy tudásom révén jobb munkaerővé váljak. & 3,68 & 1,26 & 3,91 & 1,05 \\
\hline $\begin{array}{l}\text { A mesterképzésben való részvételem arra ösztönöz, hogy fókuszáltan használjam fel a munkaidômet } \\
\text { és ezáltal jobb munkaerôvé váljak. }\end{array}$ & 3,24 & 1,28 & 3,16 & 1,20 \\
\hline $\begin{array}{l}\text { A mesterképzésben való részvételem gyakran összeütközésbe kerül a munkával kapcsolatos kötele- } \\
\text { zettségeimmel. }\end{array}$ & 3,78 & 1,27 & 3,54 & 1,24 \\
\hline $\begin{array}{l}\text { A mesterképzésben való részvételem miatt gyakran a munkahelyemen is az iskolai dolgokon jár az } \\
\text { agyam. }\end{array}$ & 3,42 & 1,29 & 3,44 & 1,20 \\
\hline $\begin{array}{l}\text { A mesterképzésben való részvételem során használt elméleti és kritikai gondolkodásmód hasznosnak } \\
\text { tûnik a munkahelyemen is. }\end{array}$ & 3,22 & 1,21 & 3,33 & 1,09 \\
\hline $\begin{array}{l}\text { A mesterképzésben való részvételem során fejlesztett kommunikációs és együttmúködési készségek a } \\
\text { munkám során is jól hasznosulnak. }\end{array}$ & 3,36 & 1,24 & 3,45 & 1,10 \\
\hline Mennyire vagy elégedett a saját életedben jelenleg megtapasztalt munka-tanulás egyensúllyal? & 3,85 & 1,23 & 3,79 & 1,27 \\
\hline $\begin{array}{l}\text { Mennyire vagy elégedett a saját életedben jelenleg megtapasztalt munka-tanulás-magánélet egyen- } \\
\text { súllyal? }\end{array}$ & 3,34 & 1,38 & 3,35 & 1,30 \\
\hline
\end{tabular}




\section{Korábbi munkavállalás tapasztalatai - második munkahelyesek és jelenleg nem dolgozók összevetése}

Kérdések

2. $\mathrm{MH}-$

korábbi munka 145 fo"

\begin{tabular}{|c|c|c|c}
\hline Átl. & Szórás & Átl. & Szórás \\
\hline 5,82 & 1,88 & 5,43 & 2,05 \\
\hline 4,24 & 1,16 & 4,46 & 0,93 \\
\hline 4,01 & 1,26 & 3,65 & 1,25 \\
\hline 4,09 & 1,09 & 4,11 & 0,77 \\
\hline 4,42 & 0,97 & 4,59 & 0,90 \\
\hline 4,08 & 1,04 & 3,92 & 0,76 \\
\hline 27,7 & 9,9 & 26,3 & 9,5 \\
\hline 95,5 & 73,2 & 77,6 & 53,6 \\
\hline 1,21 & 0,41 & 1,19 & 0,40 \\
\hline 4,01 & 1,20 & 4,19 & 1,13 \\
\hline 2,94 & 1,35 & 2,84 & 1,44 \\
\hline 3,57 & 1,33 & 3,73 & 1,12 \\
\hline 3,30 & 1,41 & 3,51 & 1,28 \\
\hline 2,90 & 1,45 & 2,51 & 1,33 \\
\hline 3,46 & 1,30 & 3,46 & 1,28 \\
\hline 3,73 & 1,13 & 3,89 & 1,10 \\
\hline 3,45 & 1,33 & 4,46 & 0,69 \\
\hline 3,44 & 1,31 & 4,19 & 0,91 \\
\hline 3,32 & 1,32 & 3,59 & 1,24 \\
\hline 3,32 & 1,35 & 3,46 & 1,22 \\
\hline 3,17 & 1,35 & 3,81 & 1,10 \\
\hline 3,08 & 1,22 & 3,27 & 1,15 \\
\hline 3,42 & 1,39 & 3,84 & 1,26 \\
\hline 3,49 & 1,03 & 1,26 \\
\hline 4,32 & 1,16 \\
\hline 4,20 & & \\
\hline
\end{tabular}

Mennyi ideig dolgoztál a korábbi munkahelyeden?

Szakmai tapasztalat szerzésének fontossága jövőbeli szakterületen.

„Tanulmányaim és megélhetésem finanszírozásához pénzre volt szükségem” - állítás fontossága.

Tapasztalat szerzésének fontossága üzleti szervezetek múködésével kapcsolatban.

„Későbbi elhelyezkedésemhez előnyös, ha van munkatapasztalatom” - állítás fontossága.

Saját autonómiám megteremtésének fontossága.

Heti átlagban hány órát dolgoztál ezen a munkahelyeden?

Mennyit kerestél egy hónapban átlagosan? (e Ft-ban, nettó összeg)

Kapcsolódott-e a szóban forgó munka az eddigi, vagy mostani tanulmányaid területéhez?

A munkahelyi tevékenységekben való részvételem segített abban, hogy több tudásra és jobb képességekre tegyek szert.

A munkahelyi tevékenységekben való részvételem hozzásegített, hogy az egyetemi tananyagot mélyebben elsajátítsam.

A munkahelyi tevékenységekben való részvételem arra ösztönzött, hogy fókuszáltan használjam fel a tanulmányaimra fordított időmet.

A munkahelyi tevékenységekben való részvételem időben gyakran ütközött a tanulmányaimmal kapcsolatos kötelezettségeimmel.

A munkahelyi tevékenységekben való részvételem miatt gyakran az iskolai tevékenységek közben is a munkahelyi dolgokon járt az agyam.

A munkahelyi tevékenységekben való részvételem során használt gyakorlatias megközelítés hasznosnak tûnt a tanulmányaim során is.

A munkahelyi tevékenységekben való részvételem során fejlesztett kommunikációs és együttmúködési készségek a tanulmányaim során is jól hasznosultak.

A mesterképzésben való részvételem segített abban, hogy több tudásra és jobb képességekre tegyek szert.

A mesterképzésben való részvételem segített abban, hogy tudásom révén jobb munkaerővé váljak.

A mesterképzésben való részvételem arra ösztönzött, hogy fókuszáltan használjam fel a munkaidőmet és ezáltal jobb munkaerôvé váljak.

A mesterképzésben való részvételem gyakran összeütközésbe került a munkával kapcsolatos kötelezettségeimmel.

A mesterképzésben való részvételem miatt gyakran a munkahelyemen is az iskolai dolgokon járt az agyam.

A mesterképzésben való részvételem során használt elméleti és kritikai gondolkodásmód hasznosnak tûnt a munkahelyemen is.

A mesterképzésben való részvételem során fejlesztett kommunikációs és együttmúködési készségek a munkám során is jól hasznosultak.

Mennyire voltál elégedett a saját életedben (abban az időszakban) megtapasztalt munka-tanulás egyensúllyal?

Mennyire voltál elégedett a saját életedben akkoriban megtapasztalt munka-tanulás-magánélet egyensúllyal? 
A négy alcsoport háttérváltozóinak és a karriertudatosság kérdéseinek átlag- és szórásértékei

\begin{tabular}{|c|c|c|c|c|c|c|c|c|}
\hline \multirow[t]{2}{*}{ Kérdések, képzett változók } & \multicolumn{2}{|c|}{ 2. MH 145 fó } & \multicolumn{2}{|c|}{ 1. MH 164 fó } & \multicolumn{2}{|c|}{$\begin{array}{l}\text { Korábban dolg. } \\
\text { most nem } 37 \text { fó }\end{array}$} & \multicolumn{2}{|c|}{$\begin{array}{l}\text { Még nem dolg. } \\
\text { Msc. alatt } 92 \text { fö }\end{array}$} \\
\hline & Átl. & Szórás & Átl. & Szórás & Átl. & Szórás & Átl. & Szórás \\
\hline Nem (nők aránya) & $69 \%$ & & $57 \%$ & & $68 \%$ & & $61 \%$ & \\
\hline Életkor & 24,23 & 1,85 & 23,90 & 1,34 & 24,05 & 1,31 & 23,60 & 1,18 \\
\hline $\begin{array}{l}\text { Tagja vagy-e, vagy részt veszel-e a tevékenységében } \\
\text { valamilyen diákszervezetnek, szakkollégiumnak, hall- } \\
\text { gatói képviseletnek? }\end{array}$ & 1,72 & 0,45 & 1,80 & 0,40 & 1,65 & 0,48 & 1,75 & 0,44 \\
\hline $\begin{array}{l}\text { Mennyi volt a mesterképzésben elvégzett előző féléved } \\
\text { tanulmányi átlaga? }\end{array}$ & 3,99 & 0,65 & 4,11 & 0,72 & 4,21 & 0,55 & 4,10 & 0,63 \\
\hline $\begin{array}{l}\text { Amennyiben már mesterképzésben voltál, mennyi volt } \\
\text { az eggyel korábbi féléved tanulmányi átlaga? }\end{array}$ & 4,07 & 0,66 & 4,09 & 0,62 & 4,21 & 0,52 & 3,98 & 0,58 \\
\hline $\begin{array}{l}\text { Összesen hány hónapnyi munkatapasztalatot szereztél } \\
\text { a mesterszak mellett? }\end{array}$ & 12,76 & 6,83 & 8,73 & 7,09 & 7,70 & 5,25 & 0,36 & 1,66 \\
\hline $\begin{array}{l}\text { Hány különböző munkahelyen dolgoztál eddig össze- } \\
\text { sen a mesterszak mellett? }\end{array}$ & 2,08 & 0,83 & 1,05 & 0,37 & 1,41 & 0,76 & 0,08 & 0,27 \\
\hline
\end{tabular}

\section{KARRIERTUDATOSSÁG KÉRDÉSEI:}

\begin{tabular}{l|c|c|c|c|c|c|c|c}
\hline $\begin{array}{l}\text { Tudatában vagyok saját erósségeimnek (karrierem } \\
\text { szempontjából). }\end{array}$ & 4,23 & 0,71 & 4,06 & 0,79 & 3,97 & 0,90 & 4,03 & 0,70 \\
\hline $\begin{array}{l}\text { Sikeresen tudom menedzselni saját munkahely-keresé- } \\
\text { semet. }\end{array}$ & 4,21 & 0,76 & 3,88 & 0,94 & 3,92 & 0,95 & 3,84 & 0,84 \\
\hline $\begin{array}{l}\text { Képes vagyok alkalmazkodni a munkaeró-piacon tör- } \\
\text { ténó változásokhoz. }\end{array}$ & 4,02 & 0,80 & 3,87 & 0,71 & 3,73 & 0,80 & 3,82 & 0,80 \\
\hline $\begin{array}{l}\text { Tisztában vagyok azzal, hogy melyek a legfontosabb } \\
\text { célok az életemben. }\end{array}$ & 4,23 & 0,89 & 4,01 & 0,95 & 4,00 & 0,94 & 4,28 & 0,84 \\
\hline $\begin{array}{l}\text { Tájékozottnak tartom magamat a munkaeró-piaci tren- } \\
\text { deket illetóen. }\end{array}$ & 3,83 & 0,94 & 3,63 & 0,91 & 3,51 & 1,02 & 3,48 & 1,01 \\
\hline $\begin{array}{l}\text { Képesnek tartom magamat arra, hogy megtervezzem } \\
\text { saját karrierutamat. }\end{array}$ & 4,14 & 0,89 & 3,82 & 0,89 & 3,84 & 1,04 & 3,96 & 0,90 \\
\hline $\begin{array}{l}\text { Úgy vélem, hogy saját szakmai karrieremet jelenleg is } \\
\text { nagyon tudatosan építem. }\end{array}$ & 4,14 & 0,88 & 3,85 & 1,00 & 3,68 & 1,27 & 3,42 & 1,12 \\
\hline $\begin{array}{l}\text { Az egyetem melletti munkavállalás elsósorban hosz- } \\
\text { szabb távú karrier céljaimat szolgálja. }\end{array}$ & $\mathbf{4 , 4 1}$ & 0,88 & $\mathbf{4 , 2 6}$ & 1,02 & $\mathbf{3 , 9 7}$ & 1,19 & $\mathbf{3 , 5 0}$ & 1,20 \\
\hline $\begin{array}{l}\text { Bízom abban, hogy sikeres munkavállalói karrier áll } \\
\text { elóttem. }\end{array}$ & 4,72 & 0,53 & 4,66 & 0,63 & $\mathbf{4 , 2 2}$ & 0,98 & 4,58 & 0,63 \\
\hline
\end{tabular}

\section{TOVÁBBI KÉPZETT VÁLTOZÓK,}

INDEXÉRTÉKEK:

\begin{tabular}{l|c|c|c|c|c|c|c|c}
\hline Átlagos órabér (eFt) & 0,96 & 0,39 & 0,93 & 0,41 & & & & \\
\hline Karriertudatosság & $\mathbf{4 , 2 1}$ & 0,52 & $\mathbf{4 , 0 1}$ & 0,58 & $\mathbf{3 , 8 7}$ & 0,78 & $\mathbf{3 , 8 8}$ & 0,55 \\
\hline A mesterszak elósegíti a munkavállalást & 3,44 & 1,00 & 3,57 & 0,79 & & & & \\
\hline A munkavégzés elősegíti a tanulást & 3,85 & 0,73 & 3,74 & 0,69 & & & & \\
\hline A munkavállalás konfliktusban áll a tanulással & 3,58 & 1,12 & 3,27 & 1,04 & & & & \\
\hline Tanulmányi átlag változása & 0,01 & 0,54 & 0,04 & 0,48 & 0,02 & 0,44 & 0,07 & 0,43
\end{tabular}




\section{A válaszadók intézmény/mesterszak szerinti megoszlása}

\begin{tabular}{|c|c|}
\hline Mesterszak megnevezése & $\begin{array}{c}\text { Kitöltôkk } \\
\text { száma }\end{array}$ \\
\hline BCE/Biztosítási és pénzügyi matematikus & 21 \\
\hline BCE/Gazdaságinformatikus & 19 \\
\hline BCE/Logisztika & 21 \\
\hline BCE/Marketing & 39 \\
\hline BCE/Pénzügy & 46 \\
\hline BCE/Számvitel & 21 \\
\hline BCE/Vállalatfejlesztés & 54 \\
\hline BCE/Vezetés-Szervezés & 62 \\
\hline BGE/Pénzügy & 13 \\
\hline BME/Kommunikáció és Média & 45 \\
\hline BME/Múszaki menedzser & 29 \\
\hline BME/Pénzügy & 23 \\
\hline BME/Pszichológia & 14 \\
\hline BME/Vezetés-Szervezés & 28 \\
\hline Összesen & 435 \\
\hline
\end{tabular}

\section{Legfontosabb eredmények a leíró statisztikák alapján}

Az összes kitöltőből jelenleg 309 fó dolgozik (ebből 164-nek első munkahelye, 145-en pedig már korábban, más munkahelyen is dolgoztak). 37 fó korábban dolgozott, jelenleg viszont úgy döntött, hogy nem dolgozik, 92 pedig mesterszakos tanulmányai mellett sem korábban, sem pedig jelenleg nem dolgozik. A jelenleg dolgozók és nem dolgozók aránya tehát 309:129, azaz a dolgozók aránya kb. 70\%, a minta alapján tehát kissé leegyszerúsítve azt mondhatjuk, hogy tíz mesterszakos nappalis hallgatóból hét dolgozik.

Mivel a minta a részvételi arány szakonkénti bontása alapján sajnos nem tekinthető reprezentatívnak (15\%-30\% közötti részvételi arányokkal találkoztunk), felmerülhet a kérdés, hogy a kitöltési hajlandóság torzít-e valamilyen irányba? A későbbi fókuszcsoportok tapasztalatai és a nyílt kérdésekre adott válaszok alapján azt láttuk, hogy mind a dolgozók, mind pedig a nem dolgozók elég határozottan képviselték álláspontjukat és érveiket, tehát a kérdőív kapcsán mindkét csoport azt érezhette, hogy fontos az érveik képviselete. A kérdőív megfogalmazásainál igyekeztünk tudatosan törekedni arra, hogy sem egyik, sem másik irányba ne befolyásoljuk a kitöltőket, neutrálisan beszéltünk a tanulás melletti munkavállalás jelenségérôl, nem foglaltunk állást egyik irányban sem. Ezzel együtt sem lehetünk teljesen biztosak abban, hogy ez az arány a tényleges sokaságban is ugyanígy néz ki, de a meginterjúvolt - részben más intézményekben múködő - szakfelelősök észleléseivel és saját becsléseinkkel nagyjából egybeesett. Feltételezhetó, hogy a vizsgált intézményekben valamivel magasabb a nappalis mesterszakos hallgatók munkavállalási aránya (70\%), mint az országos felmérések alapján korábban kimutatott $53 \%$ körüli érték.

A kitöltők átlagéletkora 24 év és átlagosan $63 \%$ volt a lányok aránya, ami szintén megfelel a teljes sokaság értékeinek. Akik dolgoznak (145 első munkahelyes és 164 fó, aki a jelenlegi munkahelyét megelőzően is dolgozott már a mesterszak alatt) a megkérdezés időpontjában átlagosan 5,49, illetve 5,07 hónapja dolgoztak a jelenlegi munkahelyükön. A két alcsoport 4,11-es, illetve 3,99-es tanulmányi átlaggal, és átlagosan 8,7, illetve 12,8 hónap munkatapasztalattal rendelkezett. A felmérés tanulsága szerint átlagosan 1,05, illetve 2,08 különböző munkáltatónál dolgoztak eddig mesterszak mellett, tehát az egyszerúség kedvéért jogosan nevezzük első, illetve második munkahelyesnek őket.

Az első jelentős különbség a heti átlagban ténylegesen munkával töltött idő mennyiségében figyelhető meg: ez 25,8 óra az elsố munkahelyükön dolgozóknál (akik zömében elsô vagy második félévesek), illetve 29,4 óra a mesterszak második évében járó, második munkahelyes hallgatóknál. A felmérésben megadott értékek alapján 930, illetve 960 Ft nettó átlagos órabért kapnak, azaz havonta átlagosan 100, illetve 116 ezer Ft nettó jövedelemre tesznek szert.

A legfontosabb munkavállalási motivációt az jelentette, hogy a munkatapasztalat elósegíti a későbbi elhelyezkedést (5-ös skálán - ahol az 1-es érték volt a „nem értek egyet” és az 5-ös a „teljes mértékben egyetértek”4,71-es átlag jött ki mindkét csoportnál), továbbá, hogy lehetôségük legyen szakmai tapasztalat megszerzésére jövőbeli szakterületükön (4,66-os átlag mindkét csoportnál). Csak ezután következett a szakmai tapasztalat szerzése általában az üzleti szervezetek múködésével kapcsolatban $(4,25$ és 4,19$)$ és a saját autonómia megteremtésének a fontossága $(4,12$ és 4,19). Az anyagi szempontok („tanulmányaim és megélhetésem finanszírozásához pénzre volt szükségem”) végeztek a fontossági rangsorban az utolsó helyen (3,94 és 4,1). Ugyanezek a fontossági sorrendek figyelhetők meg akkor is, amikor a második munkahelyükön dolgozók a korábbi munkavállalási helyzetüket értékelték és ugyanez a sorrend annál a 37 fónél is, akik korábban dolgoztak, de most nem vállaltak munkát (lásd 1. és 2. táblázatok adatait).

A legtöbben diákszövetkezeten keresztül helyezkedtek el (141 fó) és kb. ugyanennyien közvetlenül a munkáltatókkal állnak kapcsolatban vagy gyakornokként (77 fó - ebből 22 fő munkaszerződés nélkül), vagy teljes-, illetve részmunkaidős munkavállalói szerződéssel 
(77 fô). Csak 9 fó dolgozik saját vállalkozásban, hárman az egyetemen dolgoznak és további három fó tanulmányi szerződéses kapcsolatban van.

Jelenlegi munkahelyüket elsősorban az interneten illetve az állásbörzéken keresztül találták meg (138fö), a második elhelyezkedési csatornát az ismerősök jelentették (97 fó), harmadik helyen az egyetemi kapcsolatrendszer végzett (38 fö), 22 fót honlapja, vagy akár fejvadász segítségével közvetlenül „megkerestek”.

Az elméleti összefoglalóban említett szúkösségi, illetve bővítési megközelítések mentén összegezve az eredményeket a fenti két csoport esetében az 5. táblázat tartalmazza a legfontosabb képzett változók átlagértékeit az első (1. MH), illetve második munkahelyükön (2.MH) dolgozók esetében.

\section{Az első (1. MH) és második munkahelyükön (2. MH) dolgozók legfontosabb képzett változóinak értékei}

\begin{tabular}{l|c|c} 
Képzett változók & $\mathbf{1 .}$ MH & $\mathbf{2 .}$ MH \\
\hline A mesterszak elósegíti a munkavállalást & 3,57 & 3,44 \\
\hline A munkavégzés elősegíti a tanulást & 3,74 & 3,85 \\
\hline $\begin{array}{l}\text { A munkavállalás konfliktusban áll a } \\
\text { tanulással }\end{array}$ & 3,27 & 3,58 \\
\hline $\begin{array}{l}\text { Mennyire vagy elégedett a saját } \\
\text { életedben megtapasztalt munka-tanulás } \\
\text { egyensúllyal? }\end{array}$ & 3,79 & 3,85 \\
\hline $\begin{array}{l}\text { Mennyire vagy elégedett a saját életedben } \\
\text { megtapasztalt munka-tanulás-magánélet } \\
\text { egyensúllyal? }\end{array}$ & 3,35 & 3,34 \\
\hline $\begin{array}{l}\text { Tanulmányi átlag változása (korábbi } \\
\text { félévhez képest) }\end{array}$ & 0,035 & 0,005 \\
\hline Karriertudatosság & 4,01 & 4,22 \\
\hline Létszám & 145 & 164
\end{tabular}

Az első három index mögött meghúzódó kérdések átlagait a 1. táblázatban találhatjuk. Az adatok alapján azt mondhatjuk, hogy szinte alig van számottevő különbség a munkatapasztalatok mennyisége, illetve a munkahelyek száma szerint a munka-tanulás gazdagítás mértékében, egyedül a konfliktus mértéke túnik nagyobbnak a második munkahelyükön dolgozók esetében. A tanulmányi átlag egyik csoportnál sem változott szignifikáns mértékben (átlagosan szinte egyáltalán nem történt elmozdulás), illetve a tanulmányi eredmény egyik félévről a következőre történő változása annál a csoportnál, akik egyáltalán nem vállaltak munkát, ennél nagyobb mértékú volt (lásd a 3. táblázat alsó sora).

A tanulmányi átlag változásával egyébként nagyon gyenge összefüggés figyelhető meg egyéni szin- ten minden lehetséges változóval, tehát beigazolódtak azok az előzetes várakozásaink, hogy inkább a munka-tanulás-magánélet egyensúly megbillenésében és a kifáradás/kiégés mértékében csapódik le a probléma, a mesterszak elvégzése csak ritkán kerül veszélybe. Összességében a munka-tanulás egyensúllyal átlagosan hasonló mértékú elégedettséget láthatunk, mint a munkavégzés tanulásra gyakorolt pozitív hatását méró kérdések átlaga, viszont ennél szignifikánsan nagyobb elégedetlenség mutatkozik a munka-tanulás-magánélet egyensúly vonatkozásában.

Amiben a két munkavállalói csoport között van még némi különbség, az a karriertudatosság mértéke, bár ez a 0,2-es különbség nem jelentős. A karriertudatosság egyébként még ennél is alacsonyabb a jelenleg nem dolgozók esetében (3,87), és érdekes megfigyelni a „Bízom abban, hogy sikeres munkavállalói karrier áll elôttem" állítás értékét (2. táblázat alsó része), amiben a még egyáltalán nem dolgozók (4,57-es átlaggal) szinte alig különböznek a jelenleg dolgozóktól (4,66, illetve 4,72), viszont a 37 fős „korábban már dolgozott, jelenleg nem dolgozó" részminta átlaga mindegyiktől jelentősen elmarad $(4,22)$. Úgy túnik, mintha a korábbi munkavállalói státus elvesztése (vagy a munkavállalási döntés felfüggesztését eredményező negatív élmények) az önbizalom csökkenését eredményeznék náluk, hiszen esetükben lényegesen alacsonyabb munka-tanulás-magánélet egyensúly $(3,03)$ volt jellemző, mint a jelenleg dolgozók átlagértéke. Ehhez hozzájárulhat még az is, hogy valószínúleg szakmailag kevésbé értékes, alacsonyabban fizetett munkát vállaltak (2. táblázat fizetési adatai) ugyanolyan idóbeli leterheltség mellett.

\section{Sokváltozós statisztikai elemzések által feltárt eredmények}

A 309 egyetemi tanulmányai mellett jelenleg is munkát végző válaszadónk munka és tanulás gazdagítás, illetve konfliktus kérdésblokkra adott válaszait elsố lépésben faktoranalízis segítségével elemeztük. A kérdések mentén 3 faktor bontakozott ki, melyek a teljes szórásnégyzet több, mint $80 \%$-át magyarázták. Ezek közül az elsó, legnagyobb magyarázóeróvel bíró faktor a tanulásnak a munkavégzésre gyakorolt gazdagító hatását tömöríti magában. A foofaktor ugyanolyan számosságú kérdéssel feltérképezett változók esetében általában arra utal, hogy az alá tartozó kérdéseknek van leginkább „megosztó" hatásuk: azaz vannak, akik nagyon pozitívan szemlélik a mesterszakos gazdasági képzések munkaerő-piacra történő kilépésre és helytállásra gyakorolt kedvező hatását, míg mások nagyon kritikusak ebben a vonatkozásban. Ez a szórás értékében is megmutatkozik, de a három kimutatott látens változó közül az első magyarázza a teljes szórás legnagyobb részét. A gaz- 
dagítás egyes aldimenziói (készségek, magatartás, gondolkodásmód, idő) ugyanazon faktorba rendeződtek.

Ezt a korábbi elméleti megközelítések alapján várt változót a „Tanulás munkavégzésre gyakorolt gazdagító hatásának" nevezhetjük el. A második faktor, amely az előzőhöz hasonlóan egyértelmúen kibontakozik a faktoranalízis eredménytáblájából a „Munkavégzés tanulást gazdagító hatása“, ami éppen az előzőnek a fordítottja: az azzal kapcsolatos tapasztalatokat és meggyőződéseket foglalja magában, hogy az egyetem melletti munkavégzés mennyire segíti a mesterszakos tanulmányok elmélyítését, vagy éppen ellenkezőleg, mennyire gátolja azt. Az 5-ös skálán mért átlagérték mindkét változó esetében a gazdagítás mértékének jellemzésére szolgál, tehát minél nagyobb az érték, annál erőteljesebb a pozitív hatás.
Végül a harmadik látens változó a fenti két gazdagítás mértékétől függetlenül fennálló konfliktus erősségére mutat rá, részben az időráfordítás mennyisége (amely egyenesen arányos a feladatok, illetve kötelezettségek, elvárások mennyiségével), részben pedig a tevékenységek időbeli elhelyezkedése és rugalmassága (órarend, munkaidő) szempontjából. Itt is megerósítést nyert a faktoranalízis alapján a harmadik faktor léte, de annak egyik összetevője (a mesterképzés miatti nyomás begyứrúzése a munkahelyre) erősebb összefüggést mutatott a Tanulás Munka Gazdagítás faktorral, ezért ezt a változót nem számítottuk bele a,,Munka-Tanulás-Konfliktus“ változó átlagába. A rotált faktorkomponensek mátrixát a 6 . táblázat mutatja be.

\section{A rotált faktorkomponensek mátrixa}

6. táblázat

\begin{tabular}{|c|c|c|c|}
\hline & $\begin{array}{c}\text { Tanulás } \\
\text { munka } \\
\text { gazdagítás }\end{array}$ & $\begin{array}{c}\text { Munka } \\
\text { tanulás } \\
\text { gazd. }\end{array}$ & $\begin{array}{c}\text { Munka } \\
\text { tanulás } \\
\text { konfl. }\end{array}$ \\
\hline $\begin{array}{l}\text { A mesterképzésben való részvételem segít abban, hogy több tudásra és jobb képessé- } \\
\text { gekre tegyek szert. }\end{array}$ & $\mathbf{0 , 8 2}$ & 0,05 & $-0,18$ \\
\hline $\begin{array}{l}\text { A mesterképzésben való részvételem segít abban, hogy tudásom révén jobb munkaeró- } \\
\text { vé váljak. }\end{array}$ & $\mathbf{0 , 7 9}$ & 0,12 & $-0,16$ \\
\hline $\begin{array}{l}\text { A Mesterképzésben való részvételem során használt elméleti és kritikai gondolkodás- } \\
\text { mód hasznosnak túnik a munkahelyemen is. }\end{array}$ & 0,76 & 0,22 & $-0,08$ \\
\hline $\begin{array}{l}\text { A Mesterképzésben való részvételem során fejlesztett kommunikációs és együttmúkö- } \\
\text { dési készségek a munkám során is jól hasznosulnak. }\end{array}$ & 0,64 & 0,08 & $-0,18$ \\
\hline $\begin{array}{l}\text { A Mesterképzésben való részvételem arra ösztönöz, hogy fókuszáltan használjam fel a } \\
\text { munkaidômet és ezáltal jobb munkaerővé váljak. }\end{array}$ & 0,64 & 0,19 & $-0,02$ \\
\hline $\begin{array}{l}\text { A munkahelyi tevékenységekben való részvételem során használt gyakorlatias megkö- } \\
\text { zelítés hasznosnak túnik a tanulmányaim során is. }\end{array}$ & 0,19 & $\mathbf{0 , 8 2}$ & $-0,01$ \\
\hline $\begin{array}{l}\text { A munkahelyi tevékenységekben való részvételem segít abban, hogy több tudásra és } \\
\text { jobb képességekre tegyek szert. }\end{array}$ & $-0,17$ & 0,75 & 0,04 \\
\hline $\begin{array}{l}\text { A munkahelyi tevékenységekben való részvételem hozzásegít, hogy az egyetemi tan- } \\
\text { anyagot mélyebben elsajátítsam. }\end{array}$ & 0,16 & $\mathbf{0 , 7 3}$ & $-0,02$ \\
\hline $\begin{array}{l}\text { A munkahelyi tevékenységekben való részvételem során fejlesztett kommunikációs és } \\
\text { együttmúködési készségek a tanulmányaim során is jól hasznosulnak. }\end{array}$ & 0,27 & 0,56 & 0,06 \\
\hline $\begin{array}{l}\text { A munkahelyi tevékenységekben való részvételem arra ösztönöz, hogy fókuszáltan } \\
\text { használjam fel a tanulmányaimra fordított időmet. }\end{array}$ & $\mathbf{0 , 3 8}$ & $\mathbf{0 , 3 3}$ & 0,13 \\
\hline $\begin{array}{l}\text { A munkahelyi tevékenységekben való részvételem miatt gyakran az iskolai tevékenysé- } \\
\text { gek közben is a munkahelyi dolgokon jár az agyam. }\end{array}$ & $-0,16$ & 0,16 & 0,72 \\
\hline $\begin{array}{l}\text { A munkahelyi tevékenységekben való részvételem időben gyakran ütközik a tanulmá- } \\
\text { nyaimmal kapcsolatos kötelezettségeimmel. }\end{array}$ & $-0,11$ & 0,05 & $\mathbf{0 , 8 8}$ \\
\hline $\begin{array}{l}\text { A mesterképzésben való részvételem gyakran összeütközésbe kerül a munkával kap- } \\
\text { csolatos kötelezettségeimmel. }\end{array}$ & $-0,01$ & $-0,08$ & $\mathbf{0 , 8 9}$ \\
\hline $\begin{array}{l}\text { A mesterképzésben való részvételem miatt gyakran a munkahelyemen is az iskolai } \\
\text { dolgokon jár az agyam. }\end{array}$ & $\mathbf{0 , 4 5}$ & $-0,18$ & 0,25 \\
\hline \multicolumn{4}{|l|}{ Rotation Method: Varimax with Kaiser Normalization. } \\
\hline & & & \\
\hline
\end{tabular}


A gazdagítás és konfliktus dimenziók egyértelmú szétválása és faktoranalízis által történő megerősítése önmagában is izgalmas eredmény, alátámasztja azt a szerepekkel kapcsolatos várakozásunkat, hogy a gazdagítás (vagy annak hiánya) mindkét irányban értelmezhetô, és ettől valamennyire független a konfliktus megtapasztalása.

A fenti három faktor alapján képzett változók terében az SPSS K-means eljárásával klaszteranalízist készítettünk, hogy eltérő jellemzőkkel bíró, de a fenti változók mentén viszonylag homogén alcsoportokat kapjunk és ezeket külön-külön is megvizsgáljuk. Viszonylag nagy számossággal és markánsan eltérő jellemzókkel végül 5 csoportot sikerült elkülönítenünk, ezek jellemzőit mutatja a 7. táblázat (világos szürkével jelöltük a klaszterező eljárás alapját képező három faktoron mért átlagokat), alatta az MTE és MTME változók számított értékei a munka-tanulás egyensúlyt, illetve a munka-tanulás-magánélet egyensúlyt jelölik. átlagértékei

\begin{tabular}{l|c|c|c|c|c} 
Klaszterek & $\mathbf{1}$ & $\mathbf{2}$ & $\mathbf{3}$ & $\mathbf{4}$ & $\mathbf{5}$ \\
\hline Létszám & 75 & 27 & 40 & 108 & 59 \\
\hline Tan. Mun. G. & 4,05 & 2,03 & 2,44 & 3,99 & 3,36 \\
\hline Mun. Tan. G. & 4,03 & 2,72 & 4,06 & 4,13 & 3,17 \\
\hline Mun. Tan. Konf. & 2,03 & 4,43 & 4 & 4,18 & 2,94 \\
\hline MTE & 4,52 & 2,96 & 3,53 & 3,67 & 3,80 \\
\hline MTME & 3,75 & 2,85 & 3,25 & 3,15 & 3,49
\end{tabular}

Az 1-es klaszter ideális helyzetet mutat be 75 fóvel. Mindkét irányú pozitív gazdagítás és a konfliktus alacsony szintje jellemzi, amit alátámasztanak a munka-tanulás és a magánélet egyensúlyára utaló magasabb értékek is, bár itt sokkal nagyobb a nyílás az MTE és MTME változók között, mint a többi klaszternél (,,kölcsönös gazdagitás, alacsony konfliktus”). A különbség nagysága rámutat a magánélet kritikus szerepére és feltételezhetjük, hogy addig, amíg a munka-tanulás egyensúlyát alacsony konfliktusszint mellett valósítják meg, és élik ezek gazdagító hatását, a magánéletükben több konfliktust tapasztalnak, és ezeket szükséges vállalásnak észlelik az előbbiek megtapasztalásáért.

A 2-es (szerencsére relatíve kis létszámú, 27 fơs) klaszter az előzőnek éppen az ellentéte: nagyon magas konfliktus és mindkét irányban alacsony gazdagítás (azaz valójában „kölcsönös szegényités és magas konfliktus") jelentkezik, azaz egy vesztes-vesztes helyzetet ír le. Az MTE és MTME értékek is itt a legalacsonyabbak.
A 40 fóből álló 3-as csoport legfontosabb jellemzője a magas konfliktus és a mesterszak viszonylag alacsony hozzáadott értéke mellett a munkavégzés pozitív, gazdagító hatásának a megerősítése (,„alapvetôen a munkavégzés gazdagít, magas konfliktus”). Közepes mértékú MTE és MTME átlagértékek jellemzik a klasztert.

A legnagyobb létszámú, 108 fóből álló 4-es klaszter (,kölcsönös gazdagítás, magas konfliktus”) tagjai mindkét irányban elismerik a gazdagító hatást, viszont intenzíven megélik az ebből származó konfliktusokat is. Az előző csoport tagjaihoz hasonlóan szintén közepes mértékú MTE és MTME értékek jellemzik a klaszter tagjait.

Végül az 59 fós 5-ös csoport minden tekintetben kompromisszumot jelent (, kompromisszum”), mindhárom skálán átlag körüli értékekkel. Közepesnél valamivel jobb MTE és MTME értékek jellemzik a klaszterbe tartozókat.

A teljes mintára mondható, hogy az MTME alacsonyabb az MTE értékénél, következésképpen a munka-tanulás egyensúlyára való törekvésben a magánélet integrálását áldozzák fel.

Az öt klaszter további háttéradatait tekintve kevés látványos különbséget fedezhetünk fel. Az egyik szembetúnő érték, hogy a minden szempontból ideális állapotot leíró 1-es klaszter tagjai heti átlagban lényegesen kevesebbet dolgoznak, mint a többiek (23 órát), míg mondjuk a 2-es és a 3-as klaszterek tagjai 33 óra körüli átlaggal rendelkeznek. Úgy túnik tehát, hogy érvényes az a Németh (2015) kutatásából beazonosított összefüggés, hogy a kisebb időalapú konfliktus megteremti a pozitív egymásra hatás lehetôségét.

A tanulmányi átlag terén van némi különbség a klaszterek között, de itt már csak néhány tizedes jegy (0,2-0,3 körüli) eltérést tapasztalhatunk. A munkában töltött idő és összes idő sem mutat látványos eltéréseket, miképpen az átlagfizetés mértéke sem. Egyedül a vesztes-vesztes helyzetet megélő 2-es klaszter tagjainak karriertudatosságában találunk még jelentôs különbséget: 0,4-gyel alacsonyabb érték jellemzi ôket, mint a többi alcsoportot.

Továbbá itt emelnénk ki, hogy egyedül a kölcsönös gazdagítás esetében sikerül a hallgatók egy csoportjának alacsony konfliktust megélni, az egyirányú gazdagítás vagy szegényítés magas konfliktusszinttel jár. Továbbá egyirányú gazdagítás tapasztalható a munka irányából, de ez nem valósul meg fordított esetben, így felmerül, hogy mit is jelent a tanulás gazdagító hatásának hiánya magas konfliktusszint mellett? Ezt rögtön beáldozzák a hallgatók a konfliktus csökkentésére?

További adalékokat jelenthet a klaszterek jellemzéséhez a háttérváltozók, illetve más változók közötti kereszttáblák elemzése. Összhangban van a munkavégzésre fordított időmennyiséggel a „Milyen szerződéses 
formában dolgozol?" kérdésre adott válaszok eloszlása. Azok a hallgatók, akik magasabb konfliktusszintről számoltak be (2., 3., és 4. klaszter) jóval gyakrabban nyilatkoztak úgy, hogy főállású munkaviszonyban dolgoznak, mint azok, akik a konfliktust alacsonyabbnak élik meg. Itt a válaszgyakoriság 30\%-33\%-23\%, míg az 1. és 5. klaszter esetében ez $4 \%$ és $8,5 \%$.

Az elhelyezkedés módjában is felfedezhetók eltérések. A leginkább frusztrált 2. klaszter tagjait az internetes és állásbörzén történő keresés mellett elsősorban az ismerősökön keresztül történő elhelyezkedés jellemzi, (40,7\% szemben a 31,4\%-os mintaátlaggal), ugyanakkor egyetemi kapcsolatrendszerük révén egyáltalán nem számoltak be elhelyezkedésről, míg a két alacsony konfliktussal jellemezhetó klaszter tagjainál ez a csatorna felülreprezentált.

Elgondolkodtató, hogy a 2. és 3. klaszter tagjai közel 70\%-os arányban dolgoznak több, mint féléve az adott munkahelyen, miközben az első klaszter tagjai közül csak 56\%. Szintén az 1. klaszter tagjai közül majd minden harmadik $(29,4 \%) 3$ hónapnál nem régebb óta dolgozik. Ezek az arányok felvetik annak a lehetőségét, hogy az átélt konfliktus, valamint a gazdagító hatások megítélését az adott munkahelyen eltöltött hónapok száma, s ezzel összefüggésben a hallgatók kifáradása is erőteljesebben befolyásolja. A kompromisszumos 5. klaszterben közel minden harmadik hallgató 3 hónapnál kevesebb ideje van ott, míg a 3. klaszterben a 3 hónapnál nem régebben dolgozók mindössze 15\%-ot tesznek ki.

Azok a hallgatók, akik csak a munka gazdagító hatását tapasztalják meg magas konfliktusszint mellett, az átlaghoz (46\%) viszonyítva jóval gyakrabban $(67,5 \%)$ végzik ugyanott mesterszakos tanulmányaikat, mint az alapszakot. E jelenség arra hívhatja fel az oktatók figyelmét, hogy az egyes mesterszakos képzések során érdemes lehet nagyobb figyelmet fordítani arra, hogy a hallgatók számára is jól érzékelhetővé váljon azon tudáselemek, készségek és képzési célok alapszakostól eltéró jellege, mely a mesterszakos tanulmányokat igazán értékessé formálhatja gondolkodásukban.

A szakmai tapasztalat fontosságát jövőbeni szakterületükön a 2. klaszter tagjai jóval kevesebbre értékelik társaiknál (44,4\% a maximum értéknél, szemben a 72,8\%-os mintaátlaggal). Adataink alapján sajnos nem ítélhetố meg, hogy ez az ítélet a megtapasztalt magas konfliktusszint következménye, vagy önmagukra kényszerhelyzetként értelmezve, a környezeti trendekhez alkalmazkodva vállaltak munkát, ugyanakkor fontos kutatási kérdés lehet a jövőben.

A faktorok által kijelölt változók terében végzett klaszteranalízis tehát megerősítette, hogy a fenti dimenziók mentén nagyon eltérô tapasztalatokkal rendelkező, viszonylag homogén csoportok azonosíthatók be és ezek a csoportok csak kevés háttérváltozóval mutatnak (általában enyhébb szorosságú) összefüggést. Az átélt elégedettség vagy elégedetlenség (gazdagítás, konfliktus, munka-tanulás-magánélet) elsôsorban a munkáltatói, illetve konkrét egyetemre, mesterszakra jellemző gyakorlat függ vénye, illetve kimutatható egy gyengébb kapcsolat a heti munkaidő mennyiségével és az egyéni karriertudatosság mértékével is.

\section{A kérdőív nyílt kérdéseire adott válaszok elemzése}

A kérdőívben szereplő nyitott kérdések feldolgozása során arra kerestük a választ, hogy az egyes klaszterekbe sorolt dolgozó hallgatók vajon eltéró módon ítélik-e meg azokat a tényezőket, melyek a sikeres munka-tanulás-magánélet viszonyt megalapozzák, illetve milyen javaslataik lennének a jelenleg észlelt gátló tényezők csökkentésére és a felmerülő konfliktusok feloldására.

Valamennyi hallgató, ideértve az öt klaszterba tartozó dolgozói csoportok mellett a nem dolgozó hallgatók körét is - a munkahely rugalmasságát és a hallgató kiváló időmenedzsmentjét kiemelkedő fontosságúnak értékeli a munkavállaló-tanuló szerepek közötti gazdagító viszony kialakításában. Szintén általánosan megjelenő vélekedés, hogy ahhoz, hogy valaki mindkét szerepkörben képes legyen jó színvonalon teljesíteni, alapvetôen magas költségekkel kell számolnia a magánélet tekintetében, vagyis ha valaki az egyetemi tanulmányai mellett munkát vállal, az jelentős mértékú lemondást feltételez a szabadidő, a rekreáció és a társas kapcsolatok vonatkozásában. Ennek az első pillanattól történő tudatos (akár határozott, és rövidebb időre szóló) felvállalása sok feszültségtől kímélheti meg azokat, akik a hallgatói munkavállalás mellett döntenek.

Szintén közös vélekedés valamennyi csoport esetében, hogy az egyetemi órarend kialakítása sarkalatos pontja annak, hogy valaki képes-e mindkét szerepében sikeresen helytállni. Egy, a napirendet jobban szervezhetôvé tevő órarend, s a számonkérésekben megjelenő alternatív lehetőségek a többség véleménye szerint jól támogathatnák a gazdagító hatást.

A fentiek mentén körvonalazódik, hogy a hallgatók az időt észlelik legszúkösebb erőforrásként, és ezek mentén fogalmazzák meg a számukra kritikus készséget - időmenedzsment - és értékelik a munkáltató és az egyetem támogató vagy akadályozó szerepét. Azon további készségek, amelyeket még fontosnak észlelnek - priorizálás, kitartás nehéz helyzetekben vagy önfegyelem - mind az idómenedzsmenttel összefüggésben nyernek értelmet és lehetővé teszik a munka és a tanulás gazdagító hatását (de a konfliktus észlelését nem befolyásolják egyértelmúen).

Azok a hallgatók, akik a munka és a tanulás kölcsönhatását tekintve elsősorban a gazdagító hatást észlelik 
(1, 4. és 5. klaszter) - jellemzően magasabbra értékelték a saját szerepüket az optimalizálásban, míg azok, akik inkább a „,szegényítő” oldalát észlelik, az egyetem és a munkahely rugalmasságát jelölik meg kulcstényezóként. Mindez a probléma megoldása érdekében tett javaslataik arányában is jól kifejezódik, hiszen míg a 4. klaszter tagjai (kölcsönös gazdagítás, magas konfliktus) közül kb. kétszer annyian várják az egyetemtól a helyzet megoldását, addig a 3. klaszterben (csak a munka gazdagít, magas konfliktus) 4,5-szer annyian, míg a 2. klaszterben (nincs gazdagítás, magas konfliktus) 8-szor annyian vélekedtek úgy, hogy az egyetemnek kell változnia a helyzet megoldásáert. Ez a helyzetértékelés arra enged következtetni, hogy minél inkább negatívan értékeli egy hallgató a kettős szerepvállalás nyomán kialakult szituációt önmagára nézve (magas konfliktus és gyengülő gazdagító hatás), annál hajlamosabb arra, hogy a megoldást kívülről várja el.

Azok a hallgatók, akik a kölcsönös gazdagítás melletti alacsony konfliktusszintről nyilatkoztak, többségükben önmaguktól vártak változást - kiemelve a jobb fókuszálás és specializálódás képességét a még jobb időmenedzsment mellett. Jelenlegi előnyös helyzetüket szintén elsősorban önmaguknak tulajdonítják, amikor magas teherbírásukra és önfegyelmükre hivatkoznak a siker kulcsaként. A kölcsönös gazdagítás mellett magas konfliktusszintról beszámolók (4. klaszter) ugyanakkor a későbbi célok érdekében felvállalt tudatos lemondást helyezték középpontba saját sikerük zálogaként. Lehet, hogy az észlelt konfliktusszintet az befolyásolja, hogy ki, mennyire tudatosítja és mekkora áldozatnak tekinti a magánéletre fordítható idő és energia más területre való átcsoportosítását?

Azaz, ha nem tudatosítja, mert saját pozitív jellemzőjeként fogalmazza meg - magas teherbírás és önfegyelem - a konfliktust sem észleli. Ha viszont jelentôs értékvesztésként azonosítja, rögtön megjelenik a belső (és előbb-utóbb külső!) feszültség és konfliktusossá válik a kettős szerepvállalás! Az első esetben vajon kevésbé érzik, hogy alapvető elkötelezettségeik (családi, baráti, sporthoz kapcsolódó stb.) sérülnek? Vagy így vállalhatóbb, s hosszabb távon is elviselhetőbb az egyetemi munkavállalásról szóló döntés? Amennyiben így van, ez felveti a helyzet kezelése során megtapasztalható „társas támogatás” erősségének szerepét, vagyis azt, hogy miközben valaki nappalis státusban tanul, s akár szinte teljes állásban dolgozik - vajon milyen reakciókra számíthat saját személyes környezetéből? Támogatják, kritizálják, bíztatják vagy épp ultimátumokat kap az elhanyagolt ,élettereiben” jelenlévő társaitól: családtagoktól, barátoktól? A munka akkor tud gazdagító hatást kifejteni változó konfliktusszint mellett, ha a munkaadót pozitívan észlelik: rugalmas a munkavégzés, tekintettel vannak a hallgató egyetemi kötelezettségeire is, megértő a fönök stb.
A fentiek tükrében elmondható, hogy a konfliktus szintjét leginkább az idő szúkösségéből fakadó feszültségek és azok kezelésének készsége befolyásolja, míg a munka gazdagító hatásánál a munkahely jellemzői a meghatározóbbak. Az egyetem gazdagító hatásának érvényesüléséhez szükséges a pozitív hallgatói attitúd - az egyetemi tanulmányok fontosak számukra, ezért tudatosan határozzák meg a munka-tanulás határait (1. klaszter), vagy határozott idôre lemondanak a magánidőrôl (4. klaszter). Ez utóbbi összefüggés azért is érdekes, mert a gazdagító hatás nem társul az egyetem támogató szereplóként való megélésével, ugyanakkor az egyetem megjelenik, mint leküzdendó problémák forrása (magas óralátogatási kötelezettség, öncélúnak észlelt feladatok), amelyek megoldásában a hallgatók egyéni felelősségüket hangsúlyozzák, és észlelik sikerkritériumként.

A fenti eredmények értelmezésének további árnyalásában segít, ha összehasonlítjuk őket a „nem dolgozók" csoportjának tapasztalataival. Azok, akik jelenleg úgy döntöttek, hogy az egyetem mellett nem vállalnak munkát, döntésüket elsősorban a tanulmányaikra való koncentrálással és abban a minőségi teljesítmény elérésének igényével indokolták. Az egyetem melletti munkavállalással szembeni másik, gyakran előforduló döntési szempont az volt, ha párhuzamosan két, nappalis mesterszakra jár a hallgató, illetve ha egyéb, olyan aktív tevékenységet (sport, diákszervezet, demonstrátorság) végez rendszeresen, mellyel a munkába járást már összeférhetetlennek értékelné. Több válaszadónál megjelent, hogy ezt a döntést a biztos anyagi háttér jelenléte is megkönnyítette számukra. A döntés meghozatalának kiemelt befolyásoló tényezői irányítják rá a figyelmünket arra, hogy a dolgozó hallgatók ezekről nem beszéltek - így felmerül a kérdés, hogy számukra lényeges-e egyáltalán a minőségi tanulmányi teljesítmény, a „hallgatói lét” sokféle, szerteágazó tevékenységei vagy az anyagiak?

Akik korábban már dolgoztak, de jelenleg tanulmányaik miatt felfüggesztették a munkavállalásukat, azok döntő többségben úgy tapasztalták, hogy az egyetemi követelmények és a 35-40 órás munkarend nem összeegyeztethető. Ez összecseng azon korábbi állításunkkal, hogy az idő a legszúkösebb erőforrás - ha van erre vonatkozó korábbi tapasztalat, akkor a döntéshozatalban ez már lényegi szempont lesz. Továbbá feltételezhetó, hogy az egyetemi évek alatti munkavállalással szembeni attitúdjüket eddigi munkatapasztalataik, ezzel kapcsolatos feszültségeik, kudarcélményeik és a szükségszerú lemondások is jelentősen befolyásolták. Voltak azonban olyanok is, akik úgy vélekedtek, hogy nem szükséges, hogy tanulmányaik mellett ilyen fokozott terhelés alatt teljesítsenek több féléven át. 
A munka-tanulás egyensúllyal való elégedettségre vonatkozó kérdésben a válaszadók döntóen két olyan tényezőt emeltek ki, mely véleményük szerint nagymértékben hozzájárult az egyensúlyi állapot eléréséhez: a jó időmenedzsmentet és a munkahely rugalmasságát. Az egyensúly megvalósítását akadályozó tényezők közül legtöbben a párhuzamos helytállás, mint kihívás nehézségeit emelték ki.

$\mathrm{Az}$ egyensúly helyreállítása érdekében a változást legtöbben az egyetemtől várják, de második helyen önmagukat is felelősként jelölik meg a kérdésben. Figyelemreméltó, hogy ehhez képest mindössze a válaszadók 1/3-a véli úgy, hogy a munkaadó felelőssége a probléma rendezése, a válaszadók másik $1 / 3$-a pedig az érintett felek közti megoszló felelósségról ír. Az egyetemtől elsősorban a hallgatói munkavállaláshoz jobban illeszkedő órarend-szerkesztési gyakorlatot várnának el, de megfogalmazódott a házi feladatokhoz kapcsolódó terhelések csökkentése iránti igény is. Önmaguktól tudatosabb hallgatói és munkavállalói szerepvállalást, valamint egy megfelelő preferencia-sorrend felállításának képességét várják, míg az egyensúlyt jobban elősegítői munkaadói gyakorlat legfontosabb jellemzőjeként a rugalmas időbeosztás lehetőségét, illetve az otthoni munkavégzés (home office) feltételeinek megteremtését tüntették fel.

\section{Összefoglalás}

Kutatásunk kérdőíves felmérése alapján feltételezhetó, hogy a vizsgált intézményekben valamivel magasabb a nappalis mesterszakos hallgatók munkavállalási aránya (70\%), mint az országos felmérések alapján korábban kimutatott 53\% körüli érték, a legfontosabb munkavállalási motivációt pedig az a várakozás jelenti, hogy a munkatapasztalat elősegíti a későbbi elhelyezkedésüket, és szakmai tapasztalatot szerezhetnek a jövőbeli kívánatos szakterületükön, vagy általában a cégek múködésével kapcsolatban. A motivációjuk ugyanakkor nem mentes belső ellentmondásoktól sem: vannak, akik nagyon pozitívan szemlélik a mesterszakos gazdasági képzések munkaerő-piaci kilépésre és helytállásra gyakorolt kedvező hatását, és vannak, akik nagyon kritikusak ebben a vonatkozásban.

A dolgozók a munka-tanulás egyensúllyal átlagosan hasonló mértékben elégedettek, mint a munkavégzés tanulásra gyakorolt hatásával kapcsolatban, viszont ennél jóval nagyobb elégedetlenség mutatkozik a munka-tanulás-magánélet egyensúly vonatkozásában. Általánosan megjelenő vélemény volt, hogy a munka és a tanulás szerepkörében való jó teljesítménynek magas költségei vannak a magánélet területén. Az ezzel járó konfliktusszint észlelését az határozta meg, hogy ki, mennyire tudatosította és mekkora áldozatnak tekintet- te a magánéletre fordítható idő és energia más területre való átcsoportosítását. Volt, aki személyes pozitív jellemzőként fogalmazta meg - magas teherbírás, önfegyelem - és ily módon nem észlelte a belső konfliktust, sốt a pozitív énképét is erôsítette általa.

A gazdagítás és konfliktus dimenziók egyértelmú szétválását és a faktoranalízis általi megerósítését önmagában jelentős eredménynek fogalmazhatjuk meg, és alátámasztja a szerepekkel kapcsolatos korábbi feltételezéseinket, hogy a gazdagítás (vagy annak hiánya) mindkét irányban értelmezhető, és ettól valamennyire független a konfliktus megtapasztalása. Ez az eredmény részben összecseng a releváns nemzetközi és hazai szakirodalmakban leírtakkal - a szerephalmozásnak pozitív és negatív hatásai is vannak, ugyanakkor részben tovább árnyalja azt, azáltal, hogy rámutat, ezek egyszerre vannak jelen, és azonosítja azon tényezőket, amelyek e hatások érvényesülését befolyásolják.

A kutatás további lényegi eredménye a faktortérben végzett klaszteranalízis segítségével azonosított homogén hallgatói csoportok elkülönítése. Ez rámutat a hallgatói munkavállalási tapasztalatok sokszínúségére, és segít annak feltárásában, hogy a hallgatók milyen tényezőket észlelnek a sikeres alkalmazkodás alapjának, valamint milyen javaslataik vannak a gátló tényezők csökkentésére, az észlelt problémák feloldására.

Valamennyi hallgató, ideértve a nem dolgozó hallgatók körét is, a munkahely rugalmasságát, az egyetemi órarend kialakítását és a hallgatók idő́menedzsment készségeit azonosították általános érvényú, a munka-tanulás kölcsönösen gazdagító megvalósítását lehetővé tevő tényezőkként. Következésképpen elmondható, hogy a hallgatók az időt észlelik a legszúkösebb erőforrásuknak, és ennek mentén fogalmazzák meg a számukra legkritikusabb készséget - az időmenedzsmentet - és értékelik a munkáltató és az egyetem támogató vagy gátló szerepét. Az idő az észlelt konfliktusszinttel hozható egyértelmú kapcsolatba, a gazdagító/szegényítő hatás pedig további összefüggéseket is fókuszba helyez.

A gazdagító hatást a hallgatók saját maguknak tulajdonítják és változtatni is leginkább magukon akarnak ennek minél jobb megvalósulása érdekében (pl. jobb fókuszálás, specializálódás, még jobb idómenedzsment), míg „szegényítő” hatás esetén külső szereplőktől várják a változást, leginkább az egyetemtől. Érdekes megfigyelni a különbséget az egyetem és a munkáltató észlelésében: a munka gazdagító hatásánál a munkahely jellemzői a meghatározóak, míg a tanulás gazdagító hatásának érvényesüléséhez szükséges a pozitív hallgatói attitúd. Az átélt konfliktust, valamint a gazdagító hatások megítélését az adott munkahelyen eltöltött hónapok száma, s ezzel összefüggésben a hallgatók kifáradása is erőteljesen befolyásolja. 
A jelenleg nem dolgozó hallgatókkal való öszszehasonlítás két fontos tényezőre hívta fel a figyelmünket, amelyet a dolgozók nem hangsúlyoztak: a munkavállalás növelte az önbizalmat (míg a hallgatói státus nem), valamint a döntésükben nem játszik fontos szerepet az anyagi motiváció, ezáltal is igazolva korábbi, szakirodalmak alapján megfogalmazott feltevéseinket.

\section{Jegyzetek}

\begin{abstract}
' Az tanulmány a Közösen a Jövő Munkahelyeiért Alapítvány által támogatott „Egyetem melletti munkavégzés, hallgatói karrierdöntések és szerepkonfliktusok" címú kutatás adatainak felhasználásával készült.

${ }^{2}$ Aki már a második munkahelyén dolgozott a mesterszakos tanulmányai alatt, azoknál mindkettóre külön, aki korábban dolgozott, de abbahagyta, azoknál értelemszerúen csak a múltbeli tapasztalatokra tudtunk rákérdezni.
\end{abstract}

\section{Felhasznált irodalom}

Brown, S. D. - Lent, R. W. (eds.) (2013): Career Development and Counseling. Putting Theory and Research to Work. Chichester: Wiley

Carney, C. - McNeish, S.- McColl, J. (2005): The impact of part time employment on students' health and academic performance: a Scottish perspective. Journal of Further and Higher Education, Vol. 29. No. 4, p. 307-319.

Callender, C.- Kemp, M. (2000): Changing student finances: Income, expenditure and take-up of student loans among full-and part-time higher education students in 1998/9. http://dera.ioe.ac.uk/4694/1/ RR213.pdf 2016.04.18-án

Creed, P. A. - Patton, W. - Bartrum, D. (2004): Internal and external barriers, cognitive style, and the career development variables of focus and indecision. Journal of Career Development, 30, p. 277-294.

Duffy, R. D. (2010): Sense of control and career adaptibility, among undergraduates students. Journal of Career Assessment, 18., p. 420-430. DOI: $10.1177 / 1069072710374587$

Jadidian, A - Duffy, R.D. (2012): WorkVolition, Career Decision Sel-Efficacy, and Academic Satisfaction: An Examination of Mediators and Moderators. Journal of CareerAssessment, 20., p. 154-165.

Judge, T. A. - Bono, J. E. (2001): Relationship of coreself- evaluations traits-self-esteem, generalized self-efficacy, locus of control, and emotional stability - with job satisfaction and job performance: Meta-analysis. Journal of Applied Psychology, 86 (1), p. 80-92.

Ford, J. - Bosworth, D. - Wilson, R. (1995): Parttimework and full-time higher education. Studies in Higher Education, Vol.20. No.2, p. 187-202.
Forrier, A. - Sels, L. (2003): The concept employability: a complex mosaic. International Journal of Human Resources Development and Management, Vol.3. No.2, p. 102-124.

Goode, W. J. (1960): A theory of role strain. American Sociological Review, Vol. 25, No.4, p. 483-496.

Greenhaus, J. H. - Beutell, N. J. (1985): Sources of Conflict Between Work and Family Roles. Academy of Management Review, Vol.10. No.1, p. 76-88.

Greenhaus, J. H. - Powell, G. N. (2006): When work and family are allies: A Theory of Work-Family Enrichment. Academy of Management Review, Vol.31. No.1, p. 72-92.

Hodgson, A. - Spours, K. (2001): Part-timework and Full-time Education in the UK: The Emergence of a Curriculum and Policy Issue. Journal of Education and Work, Vol.14. No.3, p. 373-388.

Kiss Csaba (2013): A szervezeti elkötelezettség és a munka-család konfliktus összefüggései az ügyfélszolgálati munkában. PhD értekezés. Budapest: BCE Gazdálkodástudományi Ph.D. program

Kiss Zsuzsanna (2014): Fiatal diplomások foglalkoztathatósága Magyarországon. Debrecen: Debreceni Egyetem Közgazdaságtudományi Doktori Iskola, https://dea.lib.unideb.hu/dea/bitstream/ handle/2437/195275/Ertekezes_vegleges_KZs_t. pdf? sequence $=5 \&$ isAllowed=y 2016.08.18-án

Knight, P. T. - Yorke, M. (2006): Embedding Employability into the Curriculum. Learning and Employability Series One. York: Higher Education Academy KSH (2007): A fiatalok munkaeró-piaci helyzete. Budapest: Központi Statisztikai Hivatal, http://www. ksh.hu/pls/ksh/docs/hun/xftp/idoszaki/fiatalok/fiatalok06.pdf 2016.08.18-án

KSH (2011): A fiatalok munkaeró-piaci helyzete. Budapest: Központi Statisztikai Hivatal, http://www. ksh.hu/docs/hun/xftp/idoszaki/pdf/ifjusag_munkaero_piac.pdf2016.08.18-án

Lindsay, R. O.- Paton-Saltzberg, R. (1994): The Effects of Paid Employment on the Academic Performance of Full-time students in a British'new'University. Oxford: Oxford Brookes University

Luzzo, D. A. (2006): Exploring the Relationship between the Perception of Occupational Barriers and Career Developement. Journal of Career Development, 22, p. 239-248.

Marks, S. R. (1977): Multiple Roles and Role Strain: Some Notes on Human Energy, Time and Commitment. American Sociological Review, p. 921936.

McNall, L. A. - Michel, J. S. (2011): A Dispositional Approach to Work-School Conflict and Enrichment. Journal of Business and Psychology, Vol.26. No.3, p. 397-411. 
Moore, W. E. (1960): A Reconsideration of Theories of Social Change. American Sociological Review, p. 810-818.

Németh M. (2015): Egyetem melletti munkavégzés a Budapesti Corvinus Egyetem Gazdálkodástudományi Karának mesterszakos hallgatói körében. Szakdolgozat. Budapest: BCE

Rottinghaus, P. J. - Buelow K. L. - Matyja, A. - Schneider, M.R. (2012): The Career Futures Inventory-Revised: Measuring Dimensions of Career Adaptability. Journal of Career Assesment, 20(2), p. 123-139. DOI: 10:10.1177/106907112722429

Sieber, S. D. (1974): Toward a Theory of Role Accumulation. American Sociological Review, p. 567-578.

Silver, H. - Silver, P. (1997): Students: Changing roles, changing lives. Society for Research into Higher Education \& Open University Press, UK

Slater, P. E. (1963): On Social Regression. American Sociological Review, Vol.28. No.3, p. 339.
Snoek, J.D. (1966): Role Strain in Diversified Role Sets. American Journal of Sociology, p. 363-372.

Sorensen, L.- Winn, S. (1993): Student Loans: A Case Study. Higher Education Review, Vol.25. No.3, p. 48-65.

Veroszta Zsuzsanna (2012): Hallgatók 2011 Kutatási zárótanulmány. Educatio Társadalmi Szolgáltató Nonprofit Kft. 2016.10.08-án https://www.felvi.hu/ pub_bin/dload/DPR_hallgatoi/hallgatoi2011_zarotanulmany.pdf

Veroszta Zsuzsanna (2013): Hallgatók 2012 Kutatási zárótanulmány. Educatio Társadalmi Szolgáltató Nonprofit Kft. 2016.10.08-án http://www.felvi.hu/ pub_bin/dload/Hallgatok_2012_zarotanulmany.pdf Wyland, R. L. - Lester, S. W. - Mone, M. A. - Winkel, D. E. (2013): Work and School at the Same Time? A Conflict Perspective of the Work-School Interface. Journal of Leadership \& Organizational Studies, Vol.20. No.3, p. 346-357. 